\title{
$\mathrm{Al}_{2} \mathrm{O}_{3}$ 性质对加氢脱硫催化剂 $\mathrm{Co}-\mathrm{Mo} / \mathrm{Al}_{2} \mathrm{O}_{3}$ 活性相形成的影响
}

\author{
齐和日玛 ${ }^{1,3}$, 李会峰 ${ }^{2}$, 袁 蕙 $^{2}$, 张皿宏 ${ }^{1}$, 徐广通 ${ }^{2}$ \\ ${ }^{1}$ 北京理工大学化学物理研究所, 北京 100081 \\ 2 中国石化石油化工科学研究院, 北京 100083 \\ 3 内蒙古医学院药学院, 内蒙古呼和浩特 010059
}

摘要: 以两种商用 $\mathrm{Al}_{2} \mathrm{O}_{3}$ 为载体, 制备了汽油选择性加氢脱硫催化剂 $\mathrm{Co}-\mathrm{Mo} / \mathrm{Al}_{2} \mathrm{O}_{3}$, 并采用红外光谱、 $\mathrm{X}$ 射线衍射、 $\mathrm{N}_{2}$ 吸附-脱 附、透射电镜、扫描透射-能谱和 X 射线光电子能谱等手段系统研究了载体物化性质对催化剂活性相形成的影响. 结果表明, 表 面羟基数量少和结晶程度高的载体与活性金属间相互作用减弱, 促进了 $\mathrm{Mo}$ 物种的硫化还原, 使 $\mathrm{MoS}_{2}$ 片晶的尺寸和层数增加, 且其硫化态催化剂上 $\mathrm{CoMoS}$ 活性位更多, $\mathrm{CoMoS} / \mathrm{MoS}_{2}$ 比更大, 因而显著提高了相应 Co-Mo 催化剂加氢脱硫活性和选择性. 关键词: 氧化铝; 物化性质; 钴; 钼; 加氢脱硫; 活性相 中图分类号: O643 文献标识码: A

\section{Effect of Alumina Supports on the Formation of Active Phase of Selective Hydrodesulfurization Catalysts $\mathrm{Co}-\mathrm{Mo} / \mathrm{Al}_{2} \mathrm{O}_{3}$}

\author{
Qiherima $^{1,3}$, LI Huifeng ${ }^{2}$, YUAN Hui ${ }^{2}$, ZHANG Yunhong ${ }^{1}$, XU Guangtong ${ }^{2, *}$ \\ ${ }^{1}$ The Institute for Chemical Physics, Beijing Institute of Technology, Beijing 100081, China \\ ${ }^{2}$ Research Institute of Petroleum Processing, SINOPEC, Beijing 100083, China \\ ${ }^{3}$ Department of Pharmacy, Inner Mongolia Medical College, Hohhot 010059, Inner Mongolia, China
}

\begin{abstract}
Two different commercial alumina supports were used for the preparation of selective hydrodesulfurization (HDS) catalysts $\mathrm{Co}-\mathrm{Mo} / \mathrm{Al}_{2} \mathrm{O}_{3}$. The effect of support properties on the HDS activity and selectivity of the corresponding Co-Mo catalysts were studied by $\mathrm{X}$-ray diffraction, Fourier transform infrared spectroscopy, transmission electron microscopy, scanning transmission electron microscopyenergy dispersive X-ray spectroscopy, and X-ray photoelectron spectroscopy. The HDS activity and selectivity were measured using a continuous flow fixed-bed microreactor. The $\mathrm{Al}_{2} \mathrm{O}_{3}$ support with higher crystallinity and fewer hydroxyl groups had a moderate metal-support interaction, which resulted in an increase of the average slab length and stacking number of $\mathrm{MoS}_{2}$. This gave more formation of the active CoMoS phase and an increase in HDS activity and selectivity.
\end{abstract}

Key words: alumina; property; cobalt; molybdenum; hydrodesulfurization; active phase

$\mathrm{Al}_{2} \mathrm{O}_{3}$ 具有适宜的比表面积和孔径分布、良好的 机械强度和稳定性等良好特性, 且铝土资源较为丰 富, 因而被广泛用作催化剂载体。炼油工业中所用 的加氢处理催化剂 (除加氢裂化催化剂外) 几乎都 采用 $\mathrm{Al}_{2} \mathrm{O}_{3}$ 为载体的主要成分 ${ }^{[1]}$. 然而 $\mathrm{Al}_{2} \mathrm{O}_{3}$ 的物 化性质对负载型催化剂性能影响很大 ${ }^{[2 \sim 7]}$. Domínguez-Crespo 等 ${ }^{[5]}$ 研究了 $\mathrm{Al}_{2} \mathrm{O}_{3}$ 晶粒大小对 $\mathrm{Ni}-\mathrm{Mo} /$
$\mathrm{Al}_{2} \mathrm{O}_{3}$ 催化剂加氢脱硫 (HDS)、加氢脱氮 (HDN) 和 加氢脱芳烃 (HDA) 活性的影响. Sakashita 等 ${ }^{[6,7]}$ 报 道了 $\mathrm{Al}_{2} \mathrm{O}_{3}$ 晶面取向和结晶度与硫化态 $\mathrm{Mo} / \mathrm{Al}_{2} \mathrm{O}_{3}$ 催化剂微观结构的关系, 并指出通过调整 $\mathrm{Al}_{2} \mathrm{O}_{3}$ 载 体晶面取向可控制 $\mathrm{MoS}_{2}$ 簇的微结构. 但由于能够 用于直接测试 HDS 催化剂硫化态活性相的表征手 段有限, 有关载体的物化性质对催化剂活性相及选

收稿日期: 2010-09-21. 接收日期: 2010-10-21.

联系人: 徐广通. Tel/Fax: (010)82368613; E-mail: gtxu@sina.com

基金来源: 国家重点基础研究发展计划 (973 计划, 2006CB202506), 国家科技支撑计划 (2007BAE43B01); 石油化工催化材料与反 应工程国家重点实验室 2009 年开放课题.

本文的英文电子版由 Elsevier 出版社在 ScienceDirect 上出版(http://www.sciencedirect.com/science/journal/18722067). 
择性影响的报道较少.

为了开发高选择性的 HDS 催化剂, 本文以两种 商用 $\mathrm{Al}_{2} \mathrm{O}_{3}$ 为载体, 制备了 $\mathrm{Co}-\mathrm{Mo} / \mathrm{Al}_{2} \mathrm{O}_{3}$ 催化剂, 采 用红外光谱 (FT-IR)、 $X$ 射线衍射 (XRD)、 $N_{2}$ 吸附脱附、透射电子显微镜 (TEM)、扫描透射 - 能谱 (STEM-EDX)、X 射线光电子能谱 (XPS) 和低温 CO 吸附 FT-IR 等手段, 研究了 $\mathrm{Al}_{2} \mathrm{O}_{3}$ 载体的物化性质 与 $\mathrm{Co}-\mathrm{Mo} / \mathrm{Al}_{2} \mathrm{O}_{3}$ 的活性相及其 HDS 活性和选择性 的关系.

\section{1 实验部分}

\section{1 催化剂的制备}

以中国石化长岭催化剂厂生产的两种商用 $\mathrm{Al}_{2} \mathrm{O}_{3}$ (命名为 $\mathrm{Al}_{2} \mathrm{O}_{3}-1$ 和 $\mathrm{Al}_{2} \mathrm{O}_{3}-2$ ) 为载体, 将一定 量的硝酸钴和钿酸铵溶于氨水溶液中, 定容配制成 共浸液, 在室温浸渍氧化铝载体 $2 \mathrm{~h}$, 然后于 $393 \mathrm{~K}$ 干燥 $2 \mathrm{~h}$, 在流动空气气氛下于 $693 \mathrm{~K}$ 焙烧 $4 \mathrm{~h}$. 得 到的催化剂样品分别记为 $\mathrm{Co}-\mathrm{Mo} / \mathrm{Al}_{2} \mathrm{O}_{3}-1$ 和 $\mathrm{Co}-\mathrm{Mo} / \mathrm{Al}_{2} \mathrm{O}_{3}-2$, 其中 $\mathrm{MoO}_{3}$ 和 $\mathrm{CoO}$ 的负载量均分别 为 $8.0 \%$ 和 $2.5 \%$.

\section{2 载体和催化剂的表征}

载体的表面性质表征在 Nicolet 6700 型 FT-IR 红外光谱仪上进行, 分辨率 $4 \mathrm{~cm}^{-1}$, 扫描次数 64 次. 首先将载体磨成细粉, 然后压制成自撑片置于原位 池中密封, 升温至 $673 \mathrm{~K}$ 抽真空保持 $4 \mathrm{~h}$. 待温度降 至 $373 \mathrm{~K}$ 时采集谱图. 之后, 向原位池中通入吡啶 蒸气, 维持吸附平衡 $15 \mathrm{~min}$ 至饱和, 将体系升温至 $473 \mathrm{~K}$ 真空脱附 $30 \mathrm{~min}$ 后降至 $373 \mathrm{~K}$, 采集样品 FT-IR 谱. 然后将体系升至 $623 \mathrm{~K}$ 真空脱附 $30 \mathrm{~min}$ 后降温至 $373 \mathrm{~K}$, 采集样品谱图.

采用美国康塔公司 Autosorb-6B 型物理吸附仪 测定样品的比表面积和孔体积.

样品晶相采用 Philips 公司 XPERT 型 X 射线 衍射仪测定, $\mathrm{Cu}$ 靶 $(\lambda=0.15418 \mathrm{~nm})$, 功率 $35 \mathrm{~kW}$, 电 压 $40 \mathrm{kV}$, 电流 $50 \mathrm{~mA}$, 扫描范围 $2 \theta=5^{\circ} \sim 80^{\circ}$, 步长 $0.02 \%$.

采用 FEI 公司 Tecnai $G^{2}$ F20 S-TWIN 型透射电 子显微镜表征样品形貌, 加速电压 $200 \mathrm{kV}$, 配置 STEM 功能配件和 EDX 能谱系统. 样品超声分散 于环已烷中. 硫化态催化剂片晶的尺寸分布通过统 计约 500 个以上 $\mathrm{MoS}_{2}$ 片晶的几何参数计算得到.
$\mathrm{MoS}_{2}$ 片晶的平均长度 $(\bar{L})$ 、平均堆叠层数 $(\bar{N})$ 和 $1000 \mathrm{~nm}^{2}$ 观测面积上的 $\mathrm{MoS}_{2}$ 片晶的平均个数 $(\bar{D})$ 根据以下公式计算得到 ${ }^{[8]}$ :

$$
\begin{aligned}
& \bar{L}=\sum_{i=1}^{n} n_{i} l_{i} / \sum_{i=1}^{n} n_{i} \\
& \bar{N}=\sum_{i=1}^{n} n_{i} N_{i} / \sum_{i=1}^{n} n_{i} \\
& \bar{D}=(n / S) \times 1000
\end{aligned}
$$

用 STEM-EDX 对焙烧后氧化态催化剂上活性 组分 $C o$ 和 Mo 进行微区元素分布分析, 样品制备方 法同 TEM.

低温 CO 吸附的 FT-IR 谱在 Bruker 公司 EQUINOX 55 型 FT-IR 红外光谱仪上测定. 将氧化 态催化剂样品压成自支撑片, 放入自制低温红外石 英样品池. 先以 $10 \% \mathrm{H}_{2} \mathrm{~S}-90 \% \mathrm{H}_{2}$ 混合气体在 $673 \mathrm{~K}$ 将样品硫化 $5 \mathrm{~h}$, 然后密封降至室温. 再与高真空系 统连接, 边抽空边将样品升温到 $573 \mathrm{~K}$, 并保持 $3 \mathrm{~h}$. 然后让样品自然降到室温, 在样品池冷却夹套中注 入液氮, 使样品降温至约 $100 \mathrm{~K}$. 导入 CO 在常压下 饱和吸附约 $30 \mathrm{~min}$, 抽去气相 CO. 通过摄取样品吸 附 CO 前后差谱得其吸附 CO 的 FT-IR 谱. 实验使 用的 $\mathrm{CO}$ 经过液氮冷凝净化处理.

在 Ar 保护下, 将 CO 吸附 FT-IR 谱测试后的样 品从密封的原位池迅速转移到 Thermo Scientific 公 司 ESCALab250 型XPS 装置分析室中. 激发源为 单色化功率为 $150 \mathrm{~W}$ 的 $\mathrm{Al} K_{\alpha} \mathrm{X}$ 射线, 荷电效应用 来自载体 $\mathrm{Al}_{2} \mathrm{O}_{3}$ 的 $\mathrm{Al} 2 p$ 峰 $(74.7 \mathrm{eV})$ 校正. 谱峰拟 合时, $\mathrm{S} 2 p$ 和 Mo $3 d$ 的自旋分裂间距分别设定为理 论值 1.15 1.18 和 3.15 3.20; 峰面积比取理论值, 分别为 2.0 和 1.5 ; 自旋分裂峰如 Mo $3 d_{5 / 2}$ 和 $\mathrm{Mo}$ $3 d_{3 / 2}$ 的半高宽取相同值.

\section{3 催化剂的评价}

反应前用含 $6 \mathrm{vol} \% \mathrm{CS}_{2}$ 的环已烷溶液于 1.6 $\mathrm{MPa}, 593 \mathrm{~K}$ 对催化剂预硫化 $3 \mathrm{~h}$. 在固定床连续流 动微反装置上, 以含 $10 \%$ 噻吩和 $20 \% 1$-已烯的正庚 烷溶液为反应油, 进行 HDS 反应, 催化剂装填量 $1.00 \mathrm{~g}$. 反应条件为: $1.6 \mathrm{MPa}, 533 \mathrm{~K}$, 进料速度 0.16 $\mathrm{ml} / \mathrm{min}, \mathrm{H}_{2}$ 流速 $360 \mathrm{ml} / \mathrm{min}$. 反应达稳态后, 自动取 样, 在 Agilent 公司 6890 型气相色谱仪上进行在线 分析. 按下式计算出催化剂的 HDS 活性 $\left(X_{\mathrm{T}}\right)$ 、烯烃 饱和 (HYD) 活性 $\left(X_{\mathrm{H}}\right)$ 及 HDS 选择性因子 $(S)^{[9]}$ : $X_{\mathrm{T}}=\left[\left(w_{\mathrm{T}, 1}-w_{\mathrm{T}, 2}\right) / w_{\mathrm{T}, 1}\right], \quad X_{\mathrm{H}}=\left[\left(w_{\mathrm{H}, 1}-w_{\mathrm{H}, 2}\right) / w_{\mathrm{H}, 1}\right], \quad S=$ 
$\ln \left(1-X_{\mathrm{T}}\right) / \ln \left(1-X_{\mathrm{H}}\right)$. 其中 $w_{\mathrm{T}, 1}$ 和 $w_{\mathrm{T}, 2}$ 分别表示反应物 和产物中噻吩的质量分数, $w_{\mathrm{H}, 1}$ 和 $w_{\mathrm{H}, 2}$ 分别表示反 应物和产物中 1-已烯的质量分数.

\section{2 结果与讨论}

2.1 载体羟基、酸中心分布及其对表面金属分散性 的影响

图 1(a) 为两种 $\mathrm{Al}_{2} \mathrm{O}_{3}$ 载体的 FT-IR 谱. 可以看 出, $\mathrm{Al}_{2} \mathrm{O}_{3}-2$ 样品表面羟基数量明显少于 $\mathrm{Al}_{2} \mathrm{O}_{3}-1$. 载体上羟基的数量可能会影响负载金属组分的分 散, 因为活性金属组分在载体上沉积后会减少载体 差基的数量, 表明羟基参与了活性金属与载体间的 相互作用 ${ }^{[10]}$. 因此, 羟基较少的载体 $\mathrm{Al}_{2} \mathrm{O}_{3}-2$ 与金 属组分间的相互作用减弱, 更有利于负载于其上的 活性金属组分的硫化还原和硫化态活性相的形成. 图 1(b) 为两种载体在 473 和 $623 \mathrm{~K}$ 吸附吡啶的 FT-IR 谱, 两个温度下 $\mathrm{Al}_{2} \mathrm{O}_{3}$ 的酸量见表 1 . 两种载 体均无明显的 $\mathrm{B}$ 酸中心, 而对于 $\mathrm{L}$ 酸中心, $\mathrm{Al}_{2} \mathrm{O}_{3}-2$ 上相对较少。这表明该载体接受电子的空位较少, 可导致载体与金属组分的相互作用较弱.

为了考察载体性质对负载于其上的活性金属分 散度的影响, 本文采用 STEM-EDX 技术观察了 Co 和 Mo 组分在载体表面的分散状态, 结果见图 2. 可 以看出, 活性金属在 $\mathrm{Al}_{2} \mathrm{O}_{3}-1$ 上的分布状态比在 $\mathrm{Al}_{2} \mathrm{O}_{3}-2$ 上更均匀.
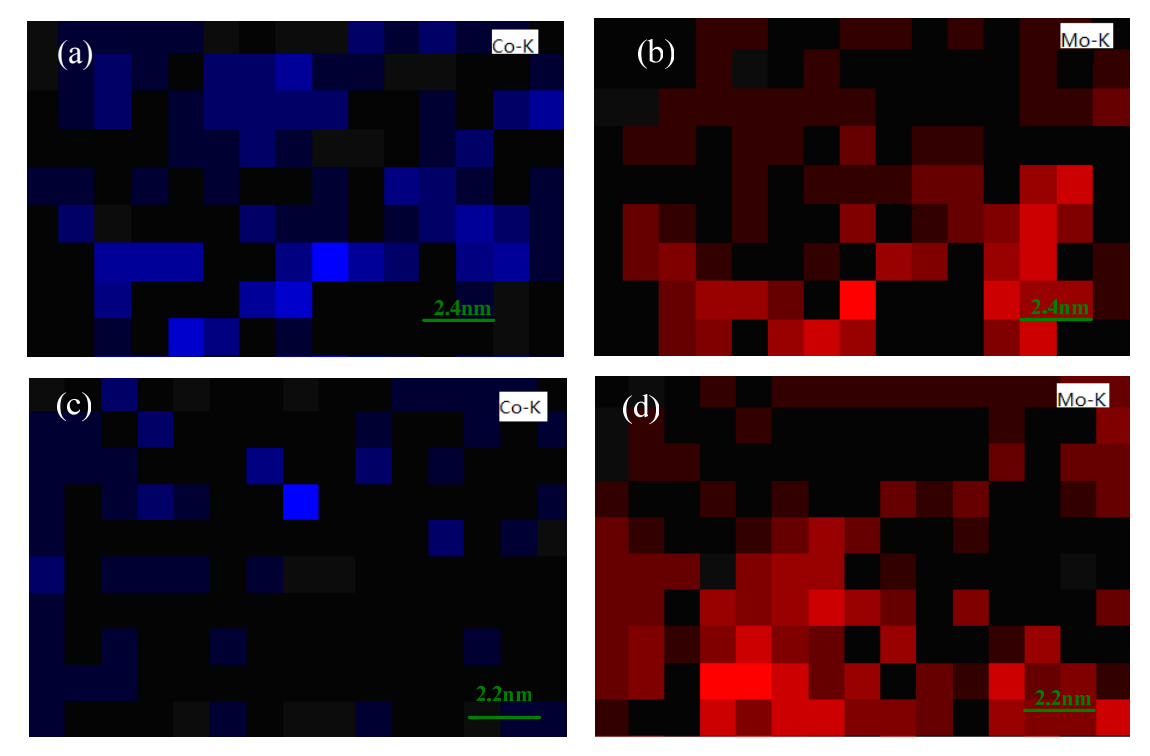

图 2 氧化态催化剂 Co-Mo/ $/ \mathrm{Al}_{2} \mathrm{O}_{3}-1$ 和 $\mathrm{Co}-\mathrm{Mo} / \mathrm{Al}_{2} \mathrm{O}_{3}-2$ 的 $\mathrm{Co}$ 和 $\mathrm{Mo}$ 元素的 STEM 面分布图

Fig. 2. Elemental mapping of $\mathrm{Co}$ and $\mathrm{Mo}$ in oxide catalysts $\mathrm{Co}-\mathrm{Mo} / \mathrm{Al}_{2} \mathrm{O}_{3}-1$ (a and b) and $\mathrm{Co}-\mathrm{Mo} / \mathrm{Al}_{2} \mathrm{O}_{3}-2$ (c and d). Red shows Mo, blue shows Co, and a lighter color shows a lower content of the element.
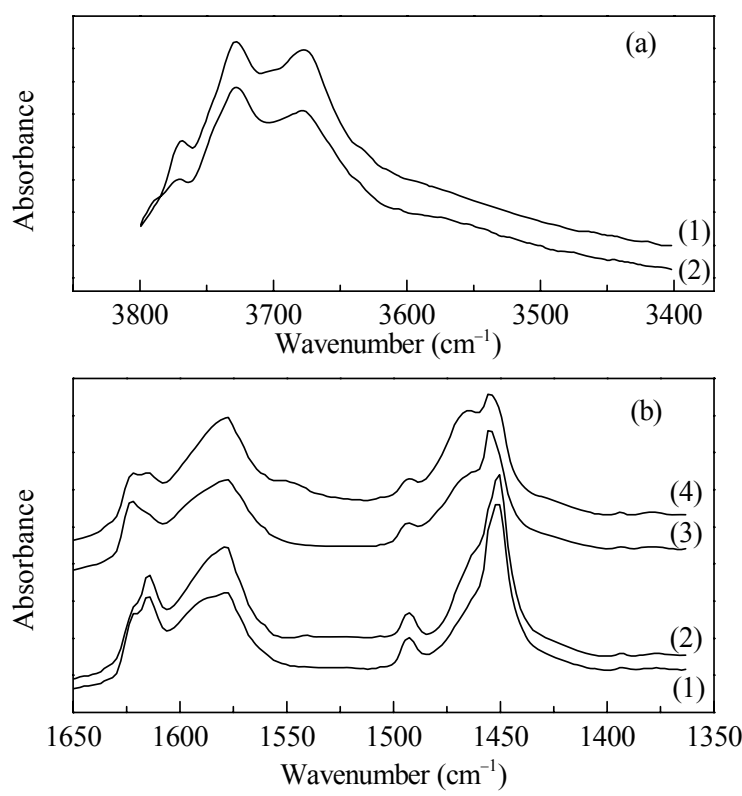

图 1 两种 $\mathrm{Al}_{2} \mathrm{O}_{3}$ 载体及其吸附吡啶的 FT-IR 谱

Fig. 1. FT-IR spectra of two $\mathrm{Al}_{2} \mathrm{O}_{3}$ supports (a) and pyridine adsorbed on the two $\mathrm{Al}_{2} \mathrm{O}_{3}$ supports at different adsorption temperatures. (a): (1) $\mathrm{Al}_{2} \mathrm{O}_{3}-1$; (2) $\mathrm{Al}_{2} \mathrm{O}_{3}-2$. (b): (1) $\mathrm{Al}_{2} \mathrm{O}_{3}-1,473 \mathrm{~K}$; (2) $\mathrm{Al}_{2} \mathrm{O}_{3}-2,473$ $\mathrm{K}$; (3) $\mathrm{Al}_{2} \mathrm{O}_{3}-1,623 \mathrm{~K}$; (4) $\mathrm{Al}_{2} \mathrm{O}_{3}-2,623 \mathrm{~K}$.

表 1 两种 $\mathrm{Al}_{2} \mathrm{O}_{3}$ 载体表面的酸含量

Table 1 Surface acid amounts of the two $\mathrm{Al}_{2} \mathrm{O}_{3}$ supports

\begin{tabular}{ccccccc}
\hline \multirow{2}{*}{ Sample $^{*}$} & \multicolumn{2}{c}{$C$ (Lewis acid $) /(\mu \mathrm{mol} / \mathrm{g})$} & & \multicolumn{2}{c}{$C($ Brönsted acid $) /(\mu \mathrm{mol} / \mathrm{g})$} \\
\cline { 2 - 3 } \cline { 5 - 6 } & $473 \mathrm{~K}$ & $623 \mathrm{~K}$ & & $473 \mathrm{~K}$ & $623 \mathrm{~K}$ \\
\hline $\mathrm{Al}_{2} \mathrm{O}_{3}-1$ & 11.0 & 8.2 & & 0 & 0 \\
$\mathrm{Al}_{2} \mathrm{O}_{3}-2$ & 7.4 & 5.8 & & 0 & 0 \\
\hline
\end{tabular}

"Two species of commercial alumina obtained from Changling Division of SINOPEC Catalyst Company. 


\section{2 载体和催化剂的织构性质和物相}

$\mathrm{Al}_{2} \mathrm{O}_{3}$ 载体和催化剂的织构性质见表 2. 由表可 见, $\mathrm{Al}_{2} \mathrm{O}_{3}-1$ 和 $\mathrm{Co}-\mathrm{Mo} / \mathrm{Al}_{2} \mathrm{O}_{3}-1$ 的比表面积和孔体积 分别大于 $\mathrm{Al}_{2} \mathrm{O}_{3}-2$ 和 $\mathrm{Co}-\mathrm{Mo} / \mathrm{Al}_{2} \mathrm{O}_{3}-2$ 的相应值, 且 催化剂比表面积和孔体积均接近于其相应载体.

表 $2 \mathrm{Al}_{2} \mathrm{O}_{3}$ 载体和 $\mathrm{Co}-\mathrm{Mo} / \mathrm{Al}_{2} \mathrm{O}_{3}$ 催化剂的织构性质

Table 2 BET surface area and pore volume of the samples

\begin{tabular}{lcc}
\hline Sample & Surface area $\left(\mathrm{m}^{2} / \mathrm{g}\right)$ & Pore volume $\left(\mathrm{cm}^{3} / \mathrm{g}\right)$ \\
\hline $\mathrm{Al}_{2} \mathrm{O}_{3}-1$ & 187 & 0.61 \\
$\mathrm{Al}_{2} \mathrm{O}_{3}-2$ & 124 & 0.56 \\
$\mathrm{Co}-\mathrm{Mo} / \mathrm{Al}_{2} \mathrm{O}_{3}-1$ & 174 & 0.53 \\
$\mathrm{Co}-\mathrm{Mo} / \mathrm{Al}_{2} \mathrm{O}_{3}-2$ & 122 & 0.47 \\
\hline
\end{tabular}

图 3 为各载体及其催化剂的 XRD 谱. 可以看 出, 两种载体均为 $\gamma-\mathrm{Al}_{2} \mathrm{O}_{3}$ 相 (PDF 48-367). 但 $\mathrm{Al}_{2} \mathrm{O}_{3}$-2 的衍射峰更尖锐, 强度更高, 说明 $\mathrm{Al}_{2} \mathrm{O}_{3}-2$ 载体结晶度更高. 从图 3 还可以看出, 金属 $\mathrm{Co}$ 和 Mo 的负载并没有明显改变相应载体的晶相, 但 $\mathrm{Co}-\mathrm{Mo} / \mathrm{Al}_{2} \mathrm{O}_{3}-2$ 样品于 $2 \theta=26.5^{\circ}$ 处出现 $\beta-\mathrm{CoMoO}_{4}$ 的特征衍射峰 (PDF 21-868), 表明该样品中 Co 和 $\mathrm{Mo}$ 较易发生相互作用. 这可能与 $\mathrm{Co}-\mathrm{Mo} / \mathrm{Al}_{2} \mathrm{O}_{3}-2$ 催化剂中 $\mathrm{Al}_{2} \mathrm{O}_{3}$-2 载体的结晶度高, 羟基量较少, 活 性组分与载体作用弱有关.

\section{3 硫化态催化剂的活性相分布特征}

为了研究载体对催化剂活性相特征的影响, 对 各硫化态催化剂进行了 TEM 表征, 结果见图 4. 由 图可见, 各催化剂 $\mathrm{MoS}_{2}$ 活性相呈典型层状堆垛结 构, 但两个样品中活性相的堆垛层数、长度和分散度 均有明显差异. 表 3 为各催化剂样品 $\mathrm{MoS}_{2}$ 片晶平

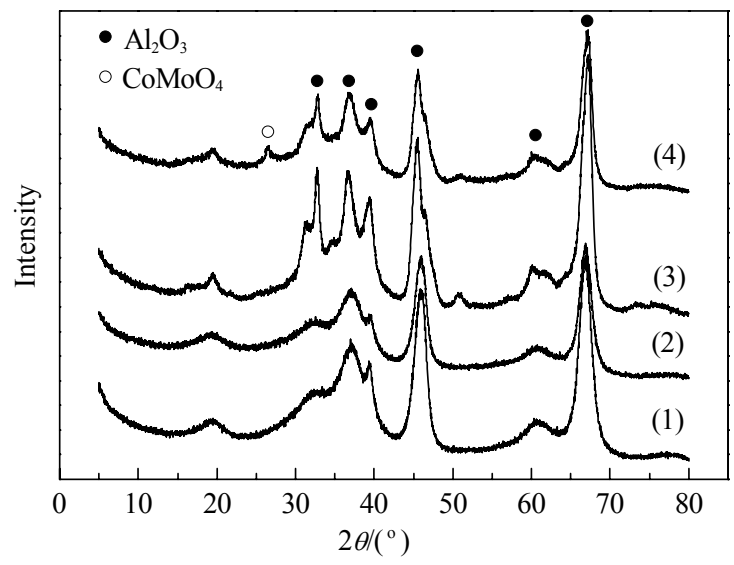

图 $3 \mathrm{Al}_{2} \mathrm{O}_{3}$ 载体和 $\mathrm{Co}-\mathrm{Mo} / \mathrm{Al}_{2} \mathrm{O}_{3}$ 氧化态催化剂的 XRD 谱

Fig. 3. XRD patterns of two supports and oxide catalysts. (1) $\mathrm{Al}_{2} \mathrm{O}_{3}-1$; (2) Co-Mo/ $\mathrm{Al}_{2} \mathrm{O}_{3}-1$; (3) $\mathrm{Al}_{2} \mathrm{O}_{3}-2$; (4) Co- $\mathrm{Mo} / \mathrm{Al}_{2} \mathrm{O}_{3}-2$.

均长度、堆叠层数和分散度. 可以看出, 与 $\mathrm{Co}-\mathrm{Mo} /$ $\mathrm{Al}_{2} \mathrm{O}_{3}-1$ 相比, $\mathrm{Co}-\mathrm{Mo} / \mathrm{Al}_{2} \mathrm{O}_{3}-2$ 的 $\mathrm{MoS}_{2}$ 片晶长度较 大, 且片晶层数也较高, 这也说明 $\mathrm{Co}-\mathrm{Mo} / \mathrm{Al}_{2} \mathrm{O}_{3}-2$ 中 金属与载体间相互作用较 $\mathrm{Co}-\mathrm{Mo} / \mathrm{Al}_{2} \mathrm{O}_{3}-1$ 弱. 研究 表明 ${ }^{[6]}$, 硫化度与堆垛层数较高的 $\mathrm{MoS}_{2}$ 片晶减弱了 $\mathrm{Al}_{2} \mathrm{O}_{3}$ 中 $\mathrm{Al}^{3+}$ 的极化作用, 促进了 $\mathrm{Co}$ 对 $\mathrm{Mo}$ 的助剂 化作用, 有利于生成高活性的 $\mathrm{CoMoS}$ 活性相.

表 3 硫化态催化剂的活性相特征统计

Table 3 Slab length, stacking number, and slab number of the sulfided $\mathrm{Co}-\mathrm{Mo} / \mathrm{Al}_{2} \mathrm{O}_{3}$ catalysts

\begin{tabular}{lccc}
\hline Sample & $\begin{array}{c}\text { Average slab } \\
\text { length }(\mathrm{nm})\end{array}$ & $\begin{array}{c}\text { Average } \\
\text { stacking } \\
\text { number }\end{array}$ & $\begin{array}{c}\text { Slab number } \\
\left(1 /\left(1000 \mathrm{~nm}^{2}\right)\right)\end{array}$ \\
\hline $\mathrm{Co}-\mathrm{Mo} / \mathrm{Al}_{2} \mathrm{O}_{3}-1$ & 4.2 & 1.6 & 12.6 \\
$\mathrm{Co}-\mathrm{Mo} / \mathrm{Al}_{2} \mathrm{O}_{3}-2$ & 5.6 & 2.3 & 8.7 \\
\hline
\end{tabular}


图 4 硫化态催化剂的 TEM 照片

Fig. 4. TEM images of the sulfided catalysts. (a) Co-Mo/ $/ \mathrm{Al}_{2} \mathrm{O}_{3}-1$; (b) $\mathrm{Co}-\mathrm{Mo} / \mathrm{Al}_{2} \mathrm{O}_{3}-2$. 


\section{4 硫化态催化剂的 XPS 结果}

各硫化态催化剂样品的 Mo $3 d$ 和 S $2 p$ XPS 谱 见图 5. 表 4 为不同化学态 Mo 和 $\mathrm{S}$ 的结合能, 与文 献报道值吻合 ${ }^{[11,12]}$. Mo $3 d$ 在 228.8 和 $232.0 \mathrm{eV}$ 显 示出强双重带, 归属于 $\mathrm{Mo}^{4+} 3 d_{5 / 2}$ 和 $\mathrm{Mo}^{4+} 3 d_{3 / 2}$ 的特 征结合能, 表明 $\mathrm{Mo}$ 主要以 $\mathrm{Mo}^{4+}$ 的形式存在. 在 232.4 和 $235.8 \mathrm{eV}$ 处较弱的谱峰是未硫化的 $\mathrm{Mo}^{6+}$ 物 种, 230.3 和 $233.6 \mathrm{eV}$ 处的峰则是 $\mathrm{O}-\mathrm{Mo}-\mathrm{S}$ 相中的 $\mathrm{Mo}^{5+}$ 物种, $\mathrm{S} 2 s$ 的峰位与 $\mathrm{Mo}^{4+} 3 d_{5 / 2}$ 较近, 谱峰有一 定的重叠, 定量分析时要除去其影响. 161.7 和 $163.0 \mathrm{eV}$ 附近呈现出 $\mathrm{S}^{2-}$ 的特征峰, 可归属于 $\mathrm{MoS}_{2}$ 相中端基 $\mathrm{S}^{2-}$ 或 $\mathrm{S}^{2-}$ 配体, 163.6 和 $164.7 \mathrm{eV}$ 处峰对 应于桥基 $\mathrm{S}_{2}{ }^{2-}$ 或氧硫形式存在的 $\mathrm{S}$ 物种, 与 $\mathrm{Mo}^{5+}$ 物 种结合生成氧硫化物 $\mathrm{MoO}_{x} \mathrm{~S}_{y}$. 在 $169.0 \mathrm{eV}$ 处没有 观察到 $\mathrm{S}$ 物种的信号, 表明硫化态催化剂没有发生 氧化现象. 由表 4 可见, 两种催化剂中各物种结合 能基本一致, 表明所研究的载体物化性质对主要物 种化学态的影响不大, 但对不同化学态物种间比值 有一定影响.

根据 XPS 谱图的分峰拟合结果, 计算催化剂中 各物种不同化学态的比值, 结果见表 4. Mo 物种的

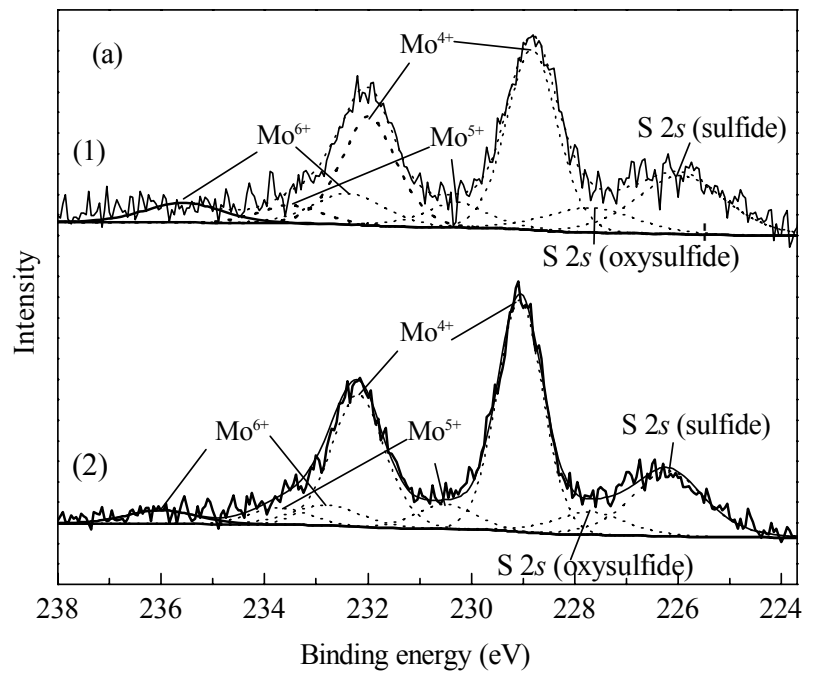

硫化度用 $n\left(\mathrm{Mo}^{4+}\right) / n(\mathrm{Mo})$ 比值来进行推算. 由表 4 可见, $\mathrm{Co}-\mathrm{Mo} / \mathrm{Al}_{2} \mathrm{O}_{3}-2$ 中 $n\left(\mathrm{Mo}^{4+}\right) / n(\mathrm{Mo})$ 比值高于 $\mathrm{Co}-\mathrm{Mo} / \mathrm{Al}_{2} \mathrm{O}_{3}-1$, 说明 $\mathrm{Co}-\mathrm{Mo} / \mathrm{Al}_{2} \mathrm{O}_{3}-2$ 中 $\mathrm{Mo}$ 的硫化 度更高, 其中 $\mathrm{Mo}^{6+}$ 物种在总 $\mathrm{Mo}$ 物种中所占比例 $n\left(\mathrm{Mo}^{6+}\right) / n(\mathrm{Mo})$ 明显少于 $\mathrm{Co}-\mathrm{Mo} / \mathrm{Al}_{2} \mathrm{O}_{3}-1$, 可见难硫 化的 $\mathrm{Mo}$ 物种在 $\mathrm{Co}-\mathrm{Mo} / \mathrm{Al}_{2} \mathrm{O}_{3}-2$ 中较少, $\mathrm{Co}-\mathrm{Mo} /$ $\mathrm{Al}_{2} \mathrm{O}_{3}-2$ 中载体与活性金属的相互作用较弱, 这与 FT-IR 和 TEM 结果一致. 需要说明的是, 由于 Co $2 p$ 的 XPS 信号很弱, 本文未对 Co $2 p$ 进行分峰拟 合. 表 4 只给出了总 Co 在载体上的分散数据 $(n(\mathrm{Co}) / n(\mathrm{Al}))$, 可以看出, $\mathrm{Co}-\mathrm{Mo} / \mathrm{Al}_{2} \mathrm{O}_{3}-2$ 中 $\mathrm{Co}$ 在载 体上的分散度比 $\mathrm{Co}-\mathrm{Mo} / \mathrm{Al}_{2} \mathrm{O}_{3}-1$ 高.

\section{5 硫化态催化剂活性相的 CO 探针吸附原位}

\section{FT-IR 结果}

低温下 $(100 \mathrm{~K}) \mathrm{CO}$ 作为一个供电子的探针分 子可吸附在硫化态 CoMo 催化剂不同形态的活性相 上, 从而可通过 CO 的 FT-IR 研究不同化学态活性 相的分布及其对催化剂性能的影响. 图 6 为两个催 化剂吸附 $\mathrm{CO}$ 后的 FT-IR 谱. $2191 \mathrm{~cm}^{-1}$ 为与载体 $\mathrm{L}$ 酸中心 $\left(\mathrm{Al}^{3+}\right)$ 结合的 $\mathrm{CO}$ 吸收峰; $2153 \mathrm{~cm}^{-1}$ 是与 载体弱酸性 $\mathrm{OH}$ 中心氢键结合的 $\mathrm{CO}$ 吸收峰. 2108

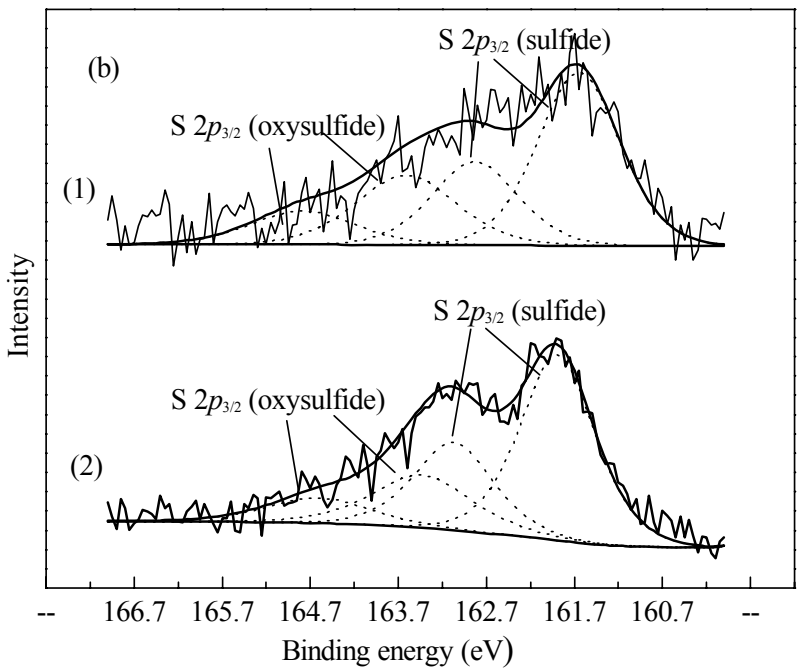

图 5 硫化态催化剂的 Mo 3d (a) 和 S 2p (b) XPS 谱

Fig. 5. Mo $3 d$ (a) and $\mathrm{S} 2 p$ (b) XPS spectra of the sulfided catalysts. (1) $\mathrm{Co}-\mathrm{Mo} / \mathrm{Al}_{2} \mathrm{O}_{3}-1$; (2) $\mathrm{Co}-\mathrm{Mo} / \mathrm{Al}_{2} \mathrm{O}_{3}-2$.

表 4 硫化态 Co-Mo/ $/ \mathrm{Al}_{2} \mathrm{O}_{3}$ 催化剂中不同物种的结合能和定量分析结果

Table 4 Binding energy and quantitative results for different species of the sulfided $\mathrm{Co}-\mathrm{Mo} / \mathrm{Al}_{2} \mathrm{O}_{3}$ catalysts

\begin{tabular}{|c|c|c|c|c|c|c|c|c|c|}
\hline \multirow{2}{*}{ Sample } & \multicolumn{5}{|c|}{ Binding energy $(\mathrm{eV})$} & \multirow{2}{*}{$\begin{array}{c}n\left(\mathrm{Mo}^{4+}\right) / \\
n(\mathrm{Mo})\end{array}$} & \multirow{2}{*}{$\begin{array}{c}N\left(\mathrm{Mo}^{5+}\right) / \\
n(\mathrm{Mo})\end{array}$} & \multirow{2}{*}{$\begin{array}{c}n\left(\mathrm{Mo}^{6+}\right) / \\
n(\mathrm{Mo})\end{array}$} & \multirow{2}{*}{$\begin{array}{c}n(\mathrm{Co}) / \\
n(\mathrm{Al})\end{array}$} \\
\hline & $\mathrm{Mo}^{4+} 3 d_{5 / 2}$ & $\mathrm{Mo}^{5+} 3 d_{5 / 2}$ & $\mathrm{Mo}^{6+} 3 d_{5 / 2}$ & $\mathrm{~S}^{2-} /$ terminal $\mathrm{S}_{2}^{2-}$ & $\mathrm{S}_{2}{ }^{2-} /$ oxysulfide $\mathrm{S}$ & & & & \\
\hline $\mathrm{Co}-\mathrm{Mo} / \mathrm{Al}_{2} \mathrm{O}_{3}-1$ & 228.8 & 230.3 & 232.4 & 161.7 & 163.6 & 72.0 & 11.6 & 16.4 & 1.3 \\
\hline $\mathrm{Co}-\mathrm{Mo} / \mathrm{Al}_{2} \mathrm{O}_{3}-2$ & 229.0 & 230.5 & 232.8 & 161.9 & 163.4 & 77.7 & 12.5 & 9.8 & 1.6 \\
\hline
\end{tabular}




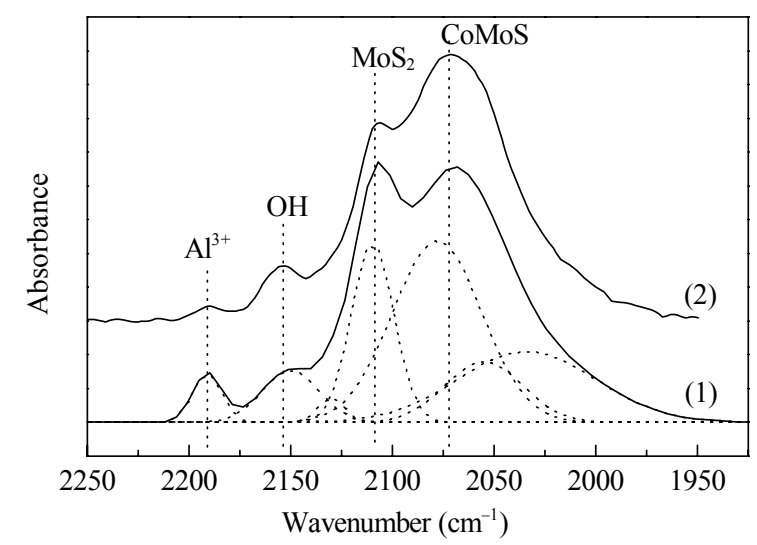

图 6 硫化态催化剂的低温吸附 CO 的 FT-IR 谱

Fig. 6. FT-IR spectra of $\mathrm{CO}$ adsorbed on the sulfided catalysts. (1) $\mathrm{Co}-\mathrm{Mo} / \mathrm{Al}_{2} \mathrm{O}_{3}-1$; (2) $\mathrm{Co}-\mathrm{Mo} / \mathrm{Al}_{2} \mathrm{O}_{3}-2$.

$\mathrm{cm}^{-1}$ 处谱峰归属于与六配位无助剂作用的 Mo 中心 结合的 $\mathrm{CO}$ 峰, 即 $\mathrm{MoS}_{2}$ 的配位不饱和位上吸附的 CO 峰; 2069 和 $2051 \mathrm{~cm}^{-1}$ 谱峰归属于有助剂作用 的活性中心上吸附的 $\mathrm{CO}$ 峰, 分别是与 $\mathrm{CO}$ 作用的 五配位和四配位且与 Co 相邻的 Mo 中心, 即 Co$\mathrm{MoS}$ 活性中心上吸附的 CO 吸收峰 ${ }^{[13]}$.

为了研究载体对各活性中心的影响, 对谱图进 行了分峰拟合. 根据 $\mathrm{CO}$ 与催化剂中各中心的作用 情况以及拟合需要, 将谱图分解为 $\mathrm{Al}^{3+}, \mathrm{OH}, \mathrm{MoS}_{2}$ 和三个 $\operatorname{CoMoS}$ 以及物理吸附等组分 ${ }^{[14,15]}$, 各峰的形 状选择高斯分布, 分峰示例见图 6. 吸附在 CoMoS 中心的 $\mathrm{CO}(\mathrm{CO}-\mathrm{CoMoS})$ 的总强度为谱图分解后三 个 CoMoS 上吸附的 CO 谱峰强度之和. CO-CoMoS 和 $\mathrm{CO}-\mathrm{MoS}_{2}$ 峰的积分面积比值 $A(\mathrm{CO}-\mathrm{CoMoS}) /$ $A\left(\mathrm{CO}-\mathrm{MoS}_{2}\right)$ 可反映硫化态催化剂的助剂化作用程 度. 结果表明, $\mathrm{Co}-\mathrm{Mo} / \mathrm{Al}_{2} \mathrm{O}_{3}-2$ 的 $\mathrm{CO}-\mathrm{CoMoS}$ 积分 面积为 6.2, 高于 $\mathrm{Co}-\mathrm{Mo} / \mathrm{Al}_{2} \mathrm{O}_{3}-1$ 的 5.6, 且 $\mathrm{Co}-\mathrm{Mo} /$ $\mathrm{Al}_{2} \mathrm{O}_{3}-2$ 的 $A(\mathrm{CO}-\mathrm{CoMoS}) / A\left(\mathrm{CO}-\mathrm{MoS}_{2}\right)$ 比值 8.33 也远高于 $\mathrm{Co}-\mathrm{Mo} / \mathrm{Al}_{2} \mathrm{O}_{3}-1$ 的 4.03 , 表明 $\mathrm{Co}-\mathrm{Mo} /$ $\mathrm{Al}_{2} \mathrm{O}_{3}-2$ 样品中高活性 $\mathrm{CoMoS}$ 相的数量及其助剂化 作用程度均高于 $\mathrm{Co}-\mathrm{Mo} / \mathrm{Al}_{2} \mathrm{O}_{3}-1$, 这将有助于提高 催化剂 HDS 活性和选择性.

\section{6 催化剂的 HDS 性能}

各催化剂 HDS 活性和选择性见表 5. 可以看 出, $\mathrm{Co}-\mathrm{Mo} / \mathrm{Al}_{2} \mathrm{O}_{3}-2$ 催化剂 $\mathrm{HDS}$ 活性明显高于 $\mathrm{Co}-\mathrm{Mo} / \mathrm{Al}_{2} \mathrm{O}_{3}-1$, 但两者烯烃饱和度基本相同, 由各 催化剂 $\mathrm{HDS}$ 选择性因子可知, $\mathrm{Co}-\mathrm{Mo} / \mathrm{Al}_{2} \mathrm{O}_{3}-2$ 催化
表 5 两种催化剂的 HDS 活性和选择性

Table 5 Evaluation of HDS activity and selectivity of $\mathrm{Co}-\mathrm{Mo} /$ $\mathrm{Al}_{2} \mathrm{O}_{3}-1$ and $\mathrm{Co}-\mathrm{Mo} / \mathrm{Al}_{2} \mathrm{O}_{3}-2$ catalysts

\begin{tabular}{lccc}
\hline Catalyst & $X_{\mathrm{T}} / \%$ & $X_{\mathrm{H}} / \%$ & $S$ \\
\hline $\mathrm{Co}-\mathrm{Mo} / \mathrm{Al}_{2} \mathrm{O}_{3}-1$ & 30.9 & 58.2 & 0.4 \\
$\mathrm{Co}-\mathrm{Mo} / \mathrm{Al}_{2} \mathrm{O}_{3}-2$ & 42.2 & 59.1 & 0.6 \\
\hline
\end{tabular}

剂 HDS 选择性更高. 结合上述表征结果可以认为, 载体结晶度高, 表面羟基和 $\mathrm{L}$ 酸中心数量少, 与金 属组分间的相互作用弱, 有利于更多的易硫化还原 的 $\mathrm{Mo}$ 物种生成; 硫化度和堆垛层数较高的 $\mathrm{MoS}_{2}$ 片晶可以减弱 $\mathrm{Al}_{2} \mathrm{O}_{3}$ 中 $\mathrm{Al}^{3+}$ 的极化作用 ${ }^{[16,17]}$, 促进 Co 对 Mo 的助剂化作用, 生成更多的 CoMoS 相, 因 而有利于提高催化剂的 HDS 活性和选择性.

\section{3 结论}

采用多种分析手段表征了两种商用 $\mathrm{Al}_{2} \mathrm{O}_{3}$ 载体 及其负载的 Co-Mo 催化剂, 并评价了催化剂的 HDS 活性和选择性. 活性金属与结晶度高、表面羟 基和 $\mathrm{L}$ 酸中心数量较少的载体 $\mathrm{Al}_{2} \mathrm{O}_{3}-2$ 间相互作用 较弱, 更易硫化还原, 且硫化度更高. 同时, 其相应 Co-Mo 催化剂上的 $\mathrm{MoS}_{2}$ 片晶尺寸更长, 层数更高. 另外, 该催化剂的 CoMoS 活性相位的数量和 $A(\mathrm{CO}-\mathrm{CoMoS}) / A\left(\mathrm{CO}-\mathrm{MoS}_{2}\right)$ 比均高于 $\mathrm{Co}-\mathrm{Mo} /$ $\mathrm{Al}_{2} \mathrm{O}_{3}$-1. 因此 $\mathrm{Co}-\mathrm{Mo} / \mathrm{Al}_{2} \mathrm{O}_{3}-2$ 催化剂上 $\mathrm{HDS}$ 活性 和选择性也更高.

\section{参考文献}

1 李大东. 加氢处理工艺与工程. 北京: 中国石化出版社 (Li D D. Hydrotreating Process and Engineering. Beijing: China Petrochemical Press), 2004. 181

2 Meephoka C, Chaisuk C, Samparnpiboon P, Praserthdam P. Catal Commum, 2008, 9: 546

3 He S B, Sun C L, Bai Z W, Dai X H, Wang B. Appl Catal $A, 2009$, 356: 88

4 Domínguez-Crespo M A, Torres-Huerta A M, Díaz-García L, Arce-Estrada E M, Ramírez-Meneses E. Fuel Process Technol, 2008, 89: 788

5 Domínguez-Crespo M A, Arce-Estrada E M, Torres-Huerta A M, Díaz-García L, de la Paz C M T. Mater Charact, 2007, 58: 864

6 Sakashita Y. Surf Sci, 2001, 489: 45

7 Sakashita Y, Araki Y, Shimada H. Appl Catal A, 2001, 215: 101

8 左东华, 聂红, Michel V, 石亚华, Michel L, 李大东. 催 化学报 (Zuo D H, Nie H, Michel V, Shi Y H, Michel L, Li 
D D. Chin J Catal), 2004, 25: 309

9 Li M F, Li H F, Jiang F, Chu Y, Nie H. Catal Today, 2010, 149: 35

10 Zepeda T A, Pawelec B, Fierro J L G, Halachev T. J Catal, 2006, 242: 254

11 Gandubert A D, Krebs E, Legens C, Costa D, Guillaume D, Raybaud P. Catal Today, 2008, 130: 149

12 Qiu L M, Xu G T. Appl Surf Sci, 2010, 256: 3413

13 Travert A, Dujardin C, Mauge F, Veilly E, Cristol S, Paul J F, Payen E. J Phys Chem B, 2006, 110: 1261

14 陈文斌. [博士学位论文]. 北京: 中国石油化工股份有限 公司石油化工科学研究院 (Chen W B. [PhD Dissertation]. Beijing: Research Institute of Petroleum Processing RIPP), 2009

15 Mueller B, van Langeveld A D, Moulijn J A, Knoezinger H. J Phys Chem, 1993, 97: 9028

16 Shimada H. Catal Today, 2003, 86: 17

17 Hensen E J M, Kooyman P J, van der Meer Y, van der Kraan A M, de Beer V H J, van Veen J A R, van Santen R A. J Catal, 2001, 199: 224

\section{英 译 文 \\ English Text}

$\mathrm{Al}_{2} \mathrm{O}_{3}$ is one of the most promising support because of its abundance and good properties such as high surface area, good pore distribution, and good stability. $\mathrm{Al}_{2} \mathrm{O}_{3}$ is widely used as the support of hydrotreating catalysts in the petroleum refining industry [1]. The different physiochemical properties of alumina can greatly influence the catalytic activity of the catalysts [2-7]. Domínguez-Crespo et al. [5] found a correlation of particle size of the alumina support with the NiMo oxide catalysts, and the final NiMoS catalyst, and reported that this was important in determining the changes of the active sites during the annealing and sulfidation steps. Sakashita et al. [6,7] investigated the effects of surface orientation and crystallinity of the support on the microstructure of supported Mo catalysts, and showed that the microstructure of the $\mathrm{MoS}_{2}$ clusters can be controlled by tailoring the surface orientation of the alumina support. However, there is little information available in the literature about the effect of alumina on the formation of the active phase and hydrodesulfurization (HDS) activity and selectivity of the corresponding CoMo catalysts due to the lack of suitable techniques that can directly provide information on the active sites.

The aim of this work is to study the effect of the surface characteristics of two different commercial alumina supports on metal-support interaction and its correlation with HDS activity and selectivity of CoMo catalysts by a variety of techniques, including X-ray diffraction analyses (XRD), Fourier transform infrared spectroscopy (FT-IR), transmis- sion electron microscopy (TEM), scanning transmission electron microscopy-energy dispersive X-ray spectroscopy (STEM-EDX), X-ray photoelectron spectrometer (XPS), and in situ FT-IR of adsorbed CO.

\section{Experimental}

\subsection{Catalyst preparation}

Two different commercial alumina, $\mathrm{Al}_{2} \mathrm{O}_{3}-1$ and $\mathrm{Al}_{2} \mathrm{O}_{3}-2$, obtained from Changling Division of SINOPEC Catalyst Company, were used without further treatment. Co-Mo/ $\mathrm{Al}_{2} \mathrm{O}_{3}-1$ and $\mathrm{Co}-\mathrm{Mo} / \mathrm{Al}_{2} \mathrm{O}_{3}-2$ with the same loading of $2.5 \%$ $\mathrm{CoO}$ and $8.0 \% \mathrm{MoO}_{3}$, were prepared by the pore volume co-impregnation method with an ammonia solution of cobalt nitrate and ammonium heptamolybdate, followed by drying at $393 \mathrm{~K}$ for $2 \mathrm{~h}$ and calcination at $693 \mathrm{~K}$ for $4 \mathrm{~h}$.

\subsection{Catalyst characterization}

The sample used for FT-IR was pressed into a self-supporting wafer and placed in an infrared cell. The sample was degassed at $673 \mathrm{~K}$ for $4 \mathrm{~h}$. Surface hydroxyl groups on the alumina were determined at $373 \mathrm{~K}$ on a Nicolet 6700 Fourier transform infrared spectrometer. Support acidity was determined after the same surface pretreatment. Pyridine was introduced into the cell at $373 \mathrm{~K}$. After adsorption for $15 \mathrm{~min}$, the sample was evacuated at $473 \mathrm{~K}$ and $623 \mathrm{~K}$, and the FT-IR spectra were recorded using 64 scans with a resolution of $4 \mathrm{~cm}^{-1}$.

The surface area and pore volume of the samples were determined by $\mathrm{N}_{2}$ physisorption using a Quantachrome Autosorb-6B automated system.

XRD patterns were recorded in the $2 \theta=5^{\circ}-80^{\circ}$ at steps of $0.02^{\circ}$ s on a Philips X'Pert diffractometer using $\mathrm{Cu} K_{\alpha}$ radiation at $0.15418 \mathrm{~nm}, 40 \mathrm{kV}$, and $50 \mathrm{~mA}$.

TEM images of the sulfided catalysts were recorded on a Tecnai $\mathrm{G}^{2}$ F20 S-TWIN microscope equipped with a STEM unit and a Thermo Noran EDX system. The particle size distribution was determined by counting about 500 particles. The average particle length $(\bar{L})$, stacking number $(\bar{N})$ and stacks per $1000 \mathrm{~nm}^{2}(\bar{D})$ were determined by manual measurement and calculated as follows [8]:

$$
\begin{aligned}
& \bar{L}=\sum_{i=1}^{n} n_{i} l_{i} / \sum_{i=1}^{n} n_{i} \\
& \bar{N}=\sum_{i=1}^{n} n_{i} N_{i} / \sum_{i=1}^{n} n_{i} \\
& \bar{D}=(n / S) \times 1000
\end{aligned}
$$

STEM-EDX was used to detect the distribution of the Co and Mo elements. The pretreatment of the sample was the same as used for TEM.

The catalyst was pressed into a self-supported wafer and placed in the IR cell. For the first procedure, the catalyst was 
dried at $423 \mathrm{~K}$ under $\mathrm{N}_{2}$ flow for $1 \mathrm{~h}$ and was then sulfided with $10 \% \mathrm{H}_{2} \mathrm{~S}$ in $\mathrm{H}_{2}$ at $673 \mathrm{~K}$. After $5 \mathrm{~h}$, the catalyst was evacuated at $573 \mathrm{~K}$ for $3 \mathrm{~h}$ and finally cooled down to $100 \mathrm{~K}$ using liquid nitrogen. $\mathrm{CO}$ adsorption was performed by the introduction of a saturation amount of $\mathrm{CO}$. The spectra of adsorbed $\mathrm{CO}$ reported in this study are subtracted spectra, i.e., the spectra of adsorbed $\mathrm{CO}$ minus the reference spectrum of the sample before $\mathrm{CO}$ adsorption.

The sulfided samples were transported into the preparation chamber of the spectrometer under the protection of argon. The spectra were recorded with a Thermo-Fishier ESCALAB $250 \mathrm{X}$-ray photoelectron spectrometer using monochromatic $150 \mathrm{~W} \mathrm{Al} K_{\alpha}$ radiations. The binding energies were referenced to the $\mathrm{Al} 2 p$ line at $74.7 \mathrm{eV}$ from the $\mathrm{Al}_{2} \mathrm{O}_{3}$ carrier. For the deconvolution of the $\mathrm{S} 2 p$ and Mo $3 d$ peaks, the following constraints were imposed: the spin-orbit splitting of the S $2 p$ and Mo $3 d$ peaks were fixed to be $1.15-1.18$ and 3.15-3.20, respectively. The area ratios of $\mathrm{S}$ $2 p$ and Mo $3 d$ peaks were equal to the theoretical values of 2.0 and 1.5 , respectively.

\subsection{Catalytic activity evaluation}

The catalysts were presulfided in situ with a sulfiding feed of $6 \mathrm{vol} \% \mathrm{CS}_{2}$ in cyclohexane at a pressure of $1.6 \mathrm{MPa}$ and temperature of $593 \mathrm{~K}$ for $3 \mathrm{~h}$. The catalytic activity tests were carried out in a continuous flow-fixed bed microreactor under the following conditions: $1.6 \mathrm{MPa}, 533 \mathrm{~K}, 1.00 \mathrm{~g}$ catalyst used, $10 \%$ thiophene and $20 \%$ 1-hexene in heptane as feed at the feed flow rate of $0.16 \mathrm{ml} / \mathrm{min}$, and a $\mathrm{H}_{2}$ flow rate of $360 \mathrm{ml} / \mathrm{min}$. After steady state conditions were reached, the liquid effluent was periodically auto-sampled and analyzed on-line by an Agilent $6890 \mathrm{~N}$ gas chromatograph. The HDS activity $\left(X_{\mathrm{T}}\right)$, hydrogenation activity $\left(X_{\mathrm{H}}\right)$ and HDS selectivity factor $(S)$ of the catalysts were calculated as follows [9]: $X_{\mathrm{T}}=\left[\left(w_{\mathrm{T}, 1}-w_{\mathrm{T}, 2}\right) / w_{\mathrm{T}, 1}\right], X_{\mathrm{H}}=\left[\left(w_{\mathrm{H}, 1}-\right.\right.$ $\left.\left.w_{\mathrm{H}, 2}\right) / w_{\mathrm{H}, 1}\right], S=\ln \left(1-X_{\mathrm{T}}\right) / \ln \left(1-X_{\mathrm{H}}\right)$. Where $w_{\mathrm{T}, 1}$ and $w_{\mathrm{T}, 2}$ denote the thiophene content in the feed and products, respectively. $w_{\mathrm{H}, 1}$ and $w_{\mathrm{H}, 2}$ denote the hexene content in the feed and products, respectively.

\section{Results and discussion}

\subsection{Distributions of hydroxyl group and acid site on the supports and their effect on the dispersion of the active metal component}

The FT-IR spectra of the hydroxyl groups on the two alumina supports are presented in Fig. 1(a). The hydroxyl group amount of $\mathrm{Al}_{2} \mathrm{O}_{3}-2$ was notably less than that of $\mathrm{Al}_{2} \mathrm{O}_{3}-1$. The nature and concentration of the hydroxyl group can play an important role in the dispersion of the supported metal species. The deposition of the catalytically active components on the supports led to a strong decrease of the intensity of the band due to the hydroxyl groups, indicating that the hydroxyl groups were involved in the interaction with the metal precursors and the dispersion of the active metal species [10]. Therefore, as compared with $\mathrm{Al}_{2} \mathrm{O}_{3}-1$, there will be a weaker interaction between the metal species and $\mathrm{Al}_{2} \mathrm{O}_{3}-2$. This would benefit the sulfidation of the metal component supported on $\mathrm{Al}_{2} \mathrm{O}_{3}-2$ and formation of the sulfided active phase.

The FT-IR spectra of the chemisorbed pyridine were used to investigate the distribution of $\mathrm{L}$ and $\mathrm{B}$ acid sites on the support. Figure 1(b) shows the spectra after adsorption of pyridine on the support. The surface acid amounts of the two supports are presented in Table 1. There were only L acid sites on the two alumina supports at the two different temperatures. The results also showed that the amount of $\mathrm{L}$ acid site of $\mathrm{Al}_{2} \mathrm{O}_{3}-1$ was more than that of $\mathrm{Al}_{2} \mathrm{O}_{3}-2$. This indicated that fewer electron vacancy sites existed on $\mathrm{Al}_{2} \mathrm{O}_{3}-2$ than on $\mathrm{Al}_{2} \mathrm{O}_{3}-1$, which would lead to a weaker interaction between the active metal component and $\mathrm{Al}_{2} \mathrm{O}_{3}-2$.

To investigate the effect of the support on metal dispersion, the STEM-EDX technique was used to observe the distribution of the Co and Mo elements on the support surface. The results are given in Fig. 2. It is clear that the distributions of the Co and Mo elements on the surface of $\mathrm{Al}_{2} \mathrm{O}_{3}-2$ supported catalyst were more even than those on the $\mathrm{Al}_{2} \mathrm{O}_{3}-1$ supported counterpart.

\subsection{Textural properties and phase analysis}

The textural properties of the samples are listed in Table 2, which shows that the surface area and pore volume of $\mathrm{Al}_{2} \mathrm{O}_{3}-2$ and $\mathrm{Co}-\mathrm{Mo} / \mathrm{Al}_{2} \mathrm{O}_{3}-2$ were smaller than those of $\mathrm{Al}_{2} \mathrm{O}_{3}-1$ and $\mathrm{Co}-\mathrm{Mo} / \mathrm{Al}_{2} \mathrm{O}_{3}-1$, respectively. It was also observed that the surface properties of $\mathrm{Co}-\mathrm{Mo} / \mathrm{Al}_{2} \mathrm{O}_{3}-1$ and $\mathrm{Co}-\mathrm{Mo} / \mathrm{Al}_{2} \mathrm{O}_{3}-2$ catalysts were very similar to those of the $\mathrm{Al}_{2} \mathrm{O}_{3}-1$ and $\mathrm{Al}_{2} \mathrm{O}_{3}-2$ supports, respectively.

The XRD patterns in Fig. 3 showed that $\mathrm{Al}_{2} \mathrm{O}_{3}-1$ and $\mathrm{Al}_{2} \mathrm{O}_{3}-2$ were both pure $\gamma$-phase (PDF 48-367), but $\mathrm{Al}_{2} \mathrm{O}_{3}-2$ has better crystallinity, which was shown by the higher intensity and narrower diffraction peak. After the loading of Co and Mo, no obvious peaks of metal oxides were observed in the XRD patterns of $\mathrm{Co}-\mathrm{Mo} / \mathrm{Al}_{2} \mathrm{O}_{3}-1$, but a small peak at $2 \theta=$ $26.5^{\circ}$, characteristic of $\beta-\mathrm{CoMoO}_{4}$ (PDF 21-868), was found in the XRD patterns of $\mathrm{Co}-\mathrm{Mo} / \mathrm{Al}_{2} \mathrm{O}_{3}-2$. This indicated that the $\mathrm{Co}$ and $\mathrm{Mo}$ species have a better interaction with $\mathrm{Al}_{2} \mathrm{O}_{3}-2$ than with $\mathrm{Al}_{2} \mathrm{O}_{3}-1$. It is suggested that this was due to fewer hydroxyl groups being present on the surface of well-crystallized $\mathrm{Al}_{2} \mathrm{O}_{3}-2$ and the weaker interaction between the active phase and $\mathrm{Al}_{2} \mathrm{O}_{3}-2$ in $\mathrm{Co}-\mathrm{Mo} / \mathrm{Al}_{2} \mathrm{O}_{3}-2$. 


\subsection{Active phase distributions of sulfided catalysts}

Representative TEM micrographs of sulfided Co-Mo/ $\mathrm{Al}_{2} \mathrm{O}_{3}-1$ and $\mathrm{Co}-\mathrm{Mo} / \mathrm{Al}_{2} \mathrm{O}_{3}-2$ are shown in Fig. 4. The photos show the well-known $\mathrm{MoS}_{2}$ slab-like structure. The average slab length, stacking number, and slab number per $1000 \mathrm{~nm}^{2}$ of the sulfided catalysts are summarized in Table 3 . There was a remarkable increase of the average slab length (from 4.2 to $5.6 \mathrm{~nm}$ ) and stacking number (from 1.6 to $2.3 \mathrm{~nm}$ ) on sulfided $\mathrm{Co}-\mathrm{Mo} / \mathrm{Al}_{2} \mathrm{O}_{3}-2$ as compared with sulfided $\mathrm{Co}-\mathrm{Mo} /$ $\mathrm{Al}_{2} \mathrm{O}_{3}-1$. This can be attributed to the weaker metal-support interaction for $\mathrm{Co}-\mathrm{Mo} / \mathrm{Al}_{2} \mathrm{O}_{3}-2$. It has been reported that an increased stacking layer of a sulfided catalyst can weaken in part the polarization of the aluminum ions on alumina surface, and exert a promoting effect of cobalt on molybdenum to form more of the CoMoS active phase.

\subsection{XPS results of sulfided catalysts}

The Mo $3 d$ and S $2 p$ XPS spectra for the sulfided Co-Mo/ $\mathrm{Al}_{2} \mathrm{O}_{3}$ catalysts are presented in Fig. 5. Their peak positions are listed in Table 4. These results are close to those reported previously [11,12]. The doublet of 228.8 and $232.0 \mathrm{eV}$ is characteristic of the sulfided $\mathrm{Mo}^{4+}$ species. This indicated that Mo was mainly in the form of $\mathrm{Mo}^{4+}$. Two relatively small peaks at about 232.4 and $235.8 \mathrm{eV}$ was attributed to unsulfided $\mathrm{Mo}^{6+}$. The peaks at 230.3 and $233.6 \mathrm{eV}$ indicated a $\mathrm{Mo}^{5+}$ species, an intermediate oxidation S-Mo-O state. The binding energy regions of the Mo $3 d$ and S $2 s$ peaks overlap. Therefore, the influence of the $\mathrm{S} 2 s$ peak must first be ruled out to get the true intensity of the Mo $3 d$ peak. The peaks located at 161.7 and $164.7 \mathrm{eV}$ corresponded to $\mathrm{S}^{2-}$ and a small fraction of terminal $\mathrm{S}_{2}{ }^{2-}$. The peak of $163.6 \mathrm{eV}$ can be assigned to bridging $\mathrm{S}_{2}{ }^{2-}$ and oxysulfide sulfur. The absence of a signal at $169.0 \mathrm{eV}$, which is that of sulfate species, indicated there was no oxidation of the catalysts during transfer from the sulfidation reactor to the XPS spectrometer. It can be seen that the support did not affect the binding energies of the Mo species in the sulfided $\mathrm{Co}-\mathrm{Mo} / \mathrm{Al}_{2} \mathrm{O}_{3}$ catalysts, which indicated that the type of Mo species present did not depend on the support. However, the support affected the relative amounts of the different chemical states.

The XPS intensity ratios of different chemical states of the main elements in the sulfided catalysts were calculated from the result of XPS peak fitting. The corresponding XPS intensity ratios for the sulfided catalysts are listed in Table 4. The sulfidation extent of Mo was determined by using the fraction of $\mathrm{Mo}^{4+}$ species in the total Mo species $n\left(\mathrm{Mo}^{4+}\right) /$ $n(\mathrm{Mo})$. It can be seen that the sulfidation extent of the Mo phase of $\mathrm{Co}-\mathrm{Mo} / \mathrm{Al}_{2} \mathrm{O}_{3}-2$ was higher than that of $\mathrm{Co}-\mathrm{Mo} /$ $\mathrm{Al}_{2} \mathrm{O}_{3}-1$. The $n\left(\mathrm{Mo}^{6+}\right) / n(\mathrm{Mo})$ ratio was significantly lower on $\mathrm{Co}-\mathrm{Mo} / \mathrm{Al}_{2} \mathrm{O}_{3}-2$ than on $\mathrm{Co}-\mathrm{Mo} / \mathrm{Al}_{2} \mathrm{O}_{3}-1$ suggesting a de- crease of unsulfided Mo species and interaction between metal species and support on $\mathrm{Co}-\mathrm{Mo} / \mathrm{Al}_{2} \mathrm{O}_{3}-2$. This was consistent with the FT-IR and TEM results. It should be noted that the Co $2 p$ XPS peaks were not deconvoluted because the Co $2 p$ XPS signals were weak. Table 4 shows only the dispersion of total Co on the support $(n(\mathrm{Co}) / n(\mathrm{Al}))$. It can be seen from Table 4 that $n(\mathrm{Co}) / n(\mathrm{Al})$ was higher on $\mathrm{Co}-\mathrm{Mo} /$ $\mathrm{Al}_{2} \mathrm{O}_{3}-2$ than on the $\mathrm{Co}-\mathrm{Mo} / \mathrm{Al}_{2} \mathrm{O}_{3}-1$.

\subsection{Distribution of active phase from in situ FT-IR}

Figure 6 shows the behavior of $\mathrm{CO}$ adsorbed on the sulfided Co-Mo/ $/ \mathrm{Al}_{2} \mathrm{O}_{3}$ with different supports. Five main bands were observed at 2191, 2153, 2108, 2069, and $2051 \mathrm{~cm}^{-1}$, respectively, which were assigned to $\mathrm{CO}$ coordinated to Lewis acid sites $\left(\mathrm{Al}^{3+}\right)$, $\mathrm{CO}$ hydrogen-bonded to acidic hydroxyl groups (Brönsted acid sites of the support), $\mathrm{CO}$ adsorbed on unpromoted Mo sites that are 6-fold coordinated Mo centers, $\mathrm{CO}$ in interaction with 5-fold and 4-fold coordinated Mo atoms adjacent to a Co atom, namely, $\mathrm{CO}$ adsorbed on CoMoS [13].

To analyze the effect of the support on the formation of unpromoted and Co-promoted sites quantitatively, the FT-IR spectra were deconvoluted. The CO spectra in the range of $1925-2250 \mathrm{~cm}^{-1}$ were decomposed into several components corresponding to interactions with $\mathrm{Al}^{3+}, \mathrm{OH}$, unpromoted Mo sites, and three kinds of Co-promoted Mo (CoMoS) sites as well as due to physical adsorption $[14,15]$. A typical deconvolution of an FT-IR spectrum is illustrated in Fig. 6. The concentrations of the Co-promoted sites were taken to be the sum of the intensities of three CO-CoMoS bands. The degree of promotion of the catalyst can be characterized by the intensity ratio of the bands of $\mathrm{CO}$ adsorbed on CoMoS (CO-CoMoS) to those on $\mathrm{MoS}_{2}$ sites $\left(\mathrm{CO}-\mathrm{MoS}_{2}\right)$. It should be noted that there was a remarkable increase in the $\mathrm{CO}-\mathrm{CoMoS}$ integral area (from 5.6 to 6.2) and $A(\mathrm{CO}-\mathrm{CoMoS}) / A\left(\mathrm{CO}-\mathrm{MoS}_{2}\right.$ ) (from 4.03 to 8.33 ) of sulfided $\mathrm{Co}-\mathrm{Mo} / \mathrm{Al}_{2} \mathrm{O}_{3}-2$ compared with those of sulfided $\mathrm{Co}-\mathrm{Mo} / \mathrm{Al}_{2} \mathrm{O}_{3}-1$. This indicated that $\mathrm{Co}$ and Mo species were able to form more of the CoMoS active phase on $\mathrm{Co}-\mathrm{Mo} / \mathrm{Al}_{2} \mathrm{O}_{3}-2$, resulting in improvement of HDS activity and selectivity.

\subsection{HDS activity of the catalysts}

The results of the HDS of thiophene are given in Table 5 . As compared with $\mathrm{Co}-\mathrm{Mo} / \mathrm{Al}_{2} \mathrm{O}_{3}-1, \mathrm{Co}-\mathrm{Mo} / \mathrm{Al}_{2} \mathrm{O}_{3}-2$ gave a higher conversion of thiophene, but the HYD activities of the two catalysts were roughly the same. A remarkable enhancement in HDS selectivity by $\mathrm{Co}-\mathrm{Mo} / \mathrm{Al}_{2} \mathrm{O}_{3}-2$ can be observed. It is clear that from the above characterization results that well-crystallized $\mathrm{Al}_{2} \mathrm{O}_{3}-2$ has less hydroxyl 
groups on its surface, which effectively weakened the metal-support interaction and led to the formation of more CoMoS species. The increased stacking layers of sulfided $\mathrm{Co}-\mathrm{Mo} / \mathrm{Al}_{2} \mathrm{O}_{3}-2$ can shield the polarization of the aluminum ions of alumina to some extent $[16,17]$, which would benefit the promoting effect of Co on Mo, and cause an increase in the formation of CoMoS species and the HDS activity and selectivity.

\section{Conclusions}

The surface characteristics of two different commercial alumina supports and their effects on metal-support interaction and the relationship with HDS activity and selectivity of the Co-Mo supported catalysts were studied by means of a variety of techniques. $\mathrm{Al}_{2} \mathrm{O}_{3}-2$ with higher crystallinity and fewer hydroxyl groups has a more moderate metal-support interaction, which improved the sulfidation of the molybdenum species, and caused a higher stacking number and longer average slab length for corresponding Co-Mo catalyst. It stimulate the more $\mathrm{CoMoS}$ active sites and a higher $A(\mathrm{CO}-\mathrm{CoMoS}) / A\left(\mathrm{CO}-\mathrm{MoS}_{2}\right)$ ratio on $\mathrm{Co}-\mathrm{Mo} / \mathrm{Al}_{2} \mathrm{O}_{3}-2$ than $\mathrm{Co}-\mathrm{Mo} / \mathrm{Al}_{2} \mathrm{O}_{3}-1$. Therefore, Co-Mo/ $/ \mathrm{Al}_{2} \mathrm{O}_{3}-2$ exhibit higher HDS activity and selectivity.

Full-text paper available online at ScienceDirect http://www.sciencedirect.com/science/journal/18722067 